Original Article

\title{
Analysis of prejudices and attitudes of students in the department of physical therapy against people with disabilities
}

\author{
Yung Keun Park, PhD ${ }^{1)}$, Je Ho KIm, PhD, $\mathrm{PT}^{2)^{*}}$ \\ 1) Department of Special Education, Sehan University, Republic of Korea \\ 2) Department of Physical Therapy, Graduate school of Physical Therapy, Sehan University: \\ 1113 Noksaek-ro, Samho-eup, Yeongam-gun, Jeollanam-do, Republic of Korea
}

\begin{abstract}
Purpose] The purpose of this study is to examine prejudices and attitudes of students in the department of physical therapy, in order to suggest basic data for constructing an effective program to develop a positive attitude toward people with disabilities and lower social distance from them. [Subjects and Methods] For this study, students in the department of physical therapy participate in the survey examining prejudices and attitude towards people with disabilities. [Results] First, there were statistically significant differences in the prejudice against people with disabilities among student groups divided by whether they had contact on a frequent basis currently with those who have disabilities. Second, there were statistically significant differences in the prejudice against people with disabilities among student groups divided by whether they had an experience of being harmed by people with disabilities. Third, there was a correlation among prejudices against people with disabilities with each other that is articulated in the eighth domain. Finally, as a result of regression analysis, the students' attitudes towards people with disabilities were explained appropriately by the prejudices about performance of daily tasks and NIMBY (Not In My Back Yard) syndrome. [Conclusion] It is crucial to create an environment where University students in the department of physical therapy can have positive interactions with people with disabilities, to reduce the overall prejudices, and specifically, the prejudices about performance of daily tasks and about NIMBY syndrome.

Key words: Prejudices and attitudes, People with disabilities
\end{abstract}

(This article was submitted Sep. 19, 2017, and was accepted Oct. 13, 2017)

\section{INTRODUCTION}

Prejudice against people with disabilities is prevalent among people without disabilities and professionals in fields related to people with disabilities. Prejudice is an emotional feeling or evaluation of group member or a person based on their perceived group membership. In this case, it can refer to a negative or positive evaluation based on unfounded beliefs and unreasonable attitude. For example, numerous people misunderstand that people with disabilities possess a negative self-image, devalue their abilities, or have a vague feeling of rejection towards them ${ }^{1}$. Such negative social perception is expressed as social prejudice, stigmatization and social distance, limiting the social integration of the people with and without disabilities. People without disabilities have a dual attitude: they agree that people with disabilities should be integrated into the society, but they are reluctant to establish personal relationships with them as neighbors, colleagues or friends. They are especially unwilling to marry them or accept them as a family member ${ }^{2}$.

As these unfair prejudices and attitudes may have a negative influence in professionals engaging in related fields, appropriate method to change them need to be implemented.

Students in the department of physical therapy enter the job field after graduating from university and have people with

*Corresponding author. Je Ho Kim (E-mail: albam20@naver.com)

(C2017 The Society of Physical Therapy Science. Published by IPEC Inc.

(c) $(-)$ This is an open-access article distributed under the terms of the Creative Commons Attribution Non-Commercial No Deriva-

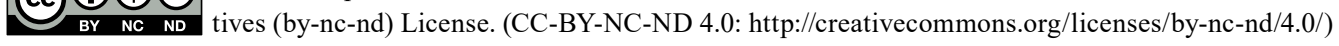


disabilities as their patients in many cases. Prejudice and misconception about people with disabilities is likely to have a negative impact on not only patients with disabilities but also physical therapists who treat them practically. Therefore, in order to enhance job satisfaction and quality of physical treatment, it is necessary to help students in the department of physical therapy eliminate prejudices against people with disabilities and develop positive attitudes before graduating and working in the field.

The purpose of this study is to examine prejudices and attitudes of students involved in the department of physical therapy. This is a practical action to eliminate discrimination and prejudice against people with disabilities and to create an integrated society where people with and without disabilities live in harmony. It could be used as basic data for establishing a strategy to develop a positive perception on people with disabilities and lower social distance from them, and for constructing an effective program to eliminate prejudices against them.

In this sense, this study intends to categorize prejudices against people with disabilities into 8 sub-domains and analyze people's attitudes towards them. It will evaluate the current perception level of students in the department of physical therapy, and on this basis, elicit a basic implication on ways to eliminate prejudices against people with disabilities. The detailed purposes of this study are as follows.

1. What are the degree of prejudice and attitudes of students in the department of physical therapy towards people with disabilities?

2. How are the degree of prejudice and attitudes towards people with disabilities different depending on background variables of students in the department of physical therapy?

3. What is the correlation among the prejudices of students in the department of physical therapy?

4. What prejudice has the greatest effect on their attitudes towards people with disabilities?

\section{SUBJECT AND METHODS}

As this study intends to examine prejudices and attitude that students in the department of physical therapy hold towards people with disabilities, the questionnaire by Yang Jieun designed to investigate prejudices and attitudes towards mental disorders was modified for this purpose ${ }^{3)}$. The participants of the study were students in the department of physical therapy currently attending University in Jeollanam-do Province. The survey period was from September 1, 2017 to September 10, 2017. A similar number of students from grade 1 to grade 4 participated, and the number of male and female students was also similar. The most common type of disability students have met was people with intellectual disability, followed by physical disability. This study was reviewed and approved by the Institutional Review Board of Sehan University (SH-IRB 2017-18) with a waiver for informed consent because the survey data were obtained anonymously.

\section{RESULTS}

The results of examining prejudices of students in the department of physical therapy towards students with disabilities are presented in Table $1(\mathrm{~F}=22.512, \mathrm{p}=0.000)$. Prejudices concerning their appearance were the strongest, while social rights was the weakest prejudice. The differences were statistically significant $(\mathrm{F}=22.512, \mathrm{p}=0.000)$. The results of studying whether there is a difference in prejudice against people with disabilities and positive attitude depending on whether they had frequent contacts with them at that time are as follows. As a result of t-test, there were statistically significant differences among student groups divided by whether they had frequent contacts with people with disabilities currently in the prejudice against people with disabilities, especially in the following domains: job and relationship with colleagues $(t=3.972, p \leq 0.05)$, NIMBY syndrome $(\mathrm{t}=4.090, \mathrm{p} \leq .05)$ and social services and government support $(\mathrm{t}=7.088, \mathrm{p} \leq 0.01)$. In addition, students having frequent contacts with people with disabilities showed a positive attitude towards them at a statistically significant level $(\mathrm{t}=4.628, \mathrm{p} \leq 0.05)$. $\mathrm{t}$ values and $\mathrm{p}$ values are included in Table 2 . This study also examined whether there is a difference in prejudices against people with disabilities and positive attitude depending on whether the students had experienced harm from them. As a result of t-test, there were statistically significant differences among student groups divided by whether they had an experience of being harmed by people with disabilities in the prejudice against people with disabilities, especially in the following domains: appearance $(\mathrm{t}=3.377, \mathrm{p} \leq 0.05)$, NIMBY syndrome $(\mathrm{t}=5.212, \mathrm{p} \leq 0.05)$ and social services and government support $(\mathrm{t}=2.381, \mathrm{p} \leq 0.05)$. Moreover, students without such experience expressed a positive attitude towards them at a statistically significant level $(t=4.976, \mathrm{p} \leq 0.05)$. $t$ values and $\mathrm{p}$ values are included in Table 2 . There is no difference in the prejudices against people with disabilities depending on the grade, gender, and experience of studying with them in school before entering University. The correlation among prejudices against people with disabilities are as follows (Table 3). There was a significant and positive correlation among prejudices against people with disabilities (from 0.31 to 0.71 , $\mathrm{p}<0.001$, two tailed), which showed that the eight domains of prejudices were significantly positively correlated with each other. The most positive and significant correlation occurred between social rights and NIMBY syndrome ( $\mathrm{r}=0.710, \mathrm{p}<0.001$, two tailed). In order to analyze how the eight prejudices students hold affect their positive attitudes toward people with disabilities, a multiple regression was conducted. Students' attitudes towards people with disabilities were set as dependent variables, and the eight prejudices were set as independent variables (Table 4). Backward regression was used to remove independent variables with insignificant regression coefficients and to construct an appropriate model. After the elimination, the students' positive 
Table 1. Prejudices against people with disabilities

\begin{tabular}{lc}
\hline Variable & Ranking \\
\hline Appearance & 1 \\
Symptoms of disability and treatment & 5 \\
Marital life and nurture of children & 4 \\
Job and relationship with colleagues & 6 \\
Performance of daily tasks & 2 \\
Social rights & 8 \\
NIMBYsyndrome & 7 \\
Social service and government support & 3 \\
\hline
\end{tabular}

Table 2. The difference of prejudice depending on background variables

\begin{tabular}{|c|c|c|c|c|c|c|c|c|c|c|c|c|}
\hline \multirow[b]{2}{*}{ Variable } & & \multirow[b]{2}{*}{ N\% } & \multicolumn{9}{|c|}{ Type of Prejudice } & \multirow[b]{2}{*}{ Attitud } \\
\hline & & & $\begin{array}{l}\text { Appear- } \\
\text { ance }\end{array}$ & $\begin{array}{l}\text { Symp- } \\
\text { toms of } \\
\text { disabil- } \\
\text { ity and } \\
\text { treat- } \\
\text { ment }\end{array}$ & $\begin{array}{l}\text { Marital } \\
\text { life and } \\
\text { nurture } \\
\text { of chil- } \\
\text { dren }\end{array}$ & $\begin{array}{l}\text { Job and } \\
\text { relation- } \\
\text { ship with } \\
\text { col- } \\
\text { leagues }\end{array}$ & $\begin{array}{l}\text { Perfor- } \\
\text { mance } \\
\text { of daily } \\
\text { tasks }\end{array}$ & $\begin{array}{l}\text { Social } \\
\text { rights }\end{array}$ & $\begin{array}{l}\text { NIMBY } \\
\text { syn- } \\
\text { drome }\end{array}$ & $\begin{array}{l}\text { Social } \\
\text { service } \\
\text { and gov- } \\
\text { ernment } \\
\text { support }\end{array}$ & Total & \\
\hline \multirow{2}{*}{$\begin{array}{l}\text { Having frequent con- } \\
\text { tacts with people with } \\
\text { disabilities }\end{array}$} & Yes & 3332 & $\begin{array}{c}2.61 \pm \\
0.81\end{array}$ & $\begin{array}{c}1.97 \pm \\
0.60\end{array}$ & $\begin{array}{c}2.14 \pm \\
0.71\end{array}$ & $\begin{array}{c}1.87 \pm \\
0.73\end{array}$ & $\begin{array}{c}2.19 \pm \\
0.77\end{array}$ & $\begin{array}{c}1.63 \pm \\
0.82\end{array}$ & $\begin{array}{c}1.71 \pm \\
0.80\end{array}$ & $\begin{array}{c}1.93 \pm \\
0.62\end{array}$ & $\begin{array}{c}2.01 \pm \\
0.56\end{array}$ & $\begin{array}{c}4.08 \pm \\
0.80\end{array}$ \\
\hline & No & 4443 & $\begin{array}{c}2.56 \pm \\
0.71\end{array}$ & $\begin{array}{c}2.12 \pm \\
0.56\end{array}$ & $\begin{array}{c}2.13 \pm \\
0.65\end{array}$ & $\begin{array}{c}2.17 \pm \\
0.60^{*}\end{array}$ & $\begin{array}{c}2.35 \pm \\
0.61\end{array}$ & $\begin{array}{c}1.69 \pm \\
0.75\end{array}$ & $\begin{array}{c}2.04 \pm \\
0.65^{*}\end{array}$ & $\begin{array}{c}2.36 \pm \\
0.66^{*}\end{array}$ & $\begin{array}{c}2.18 \pm \\
0.46\end{array}$ & $\begin{array}{c}3.71 \pm \\
0.68 *\end{array}$ \\
\hline \multirow{2}{*}{$\begin{array}{l}\text { Experience of studying } \\
\text { with people with } \\
\text { disabilities }\end{array}$} & Yes & 3332 & $\begin{array}{c}2.40 \pm \\
0.78\end{array}$ & $\begin{array}{c}1.99 \pm \\
0.59\end{array}$ & $\begin{array}{c}2.00 \pm \\
0.68\end{array}$ & $\begin{array}{c}2.02 \pm \\
0.69\end{array}$ & $\begin{array}{c}2.17 \pm \\
0.68\end{array}$ & $\begin{array}{c}1.60 \pm \\
0.74\end{array}$ & $\begin{array}{c}1.87 \pm \\
0.69\end{array}$ & $\begin{array}{c}2.21 \pm \\
0.69\end{array}$ & $\begin{array}{c}2.03 \pm \\
0.51\end{array}$ & $\begin{array}{c}3.74 \pm \\
4.03\end{array}$ \\
\hline & No & 4443 & $\begin{array}{c}2.55 \pm \\
0.72\end{array}$ & $\begin{array}{c}2.06 \pm \\
0.61\end{array}$ & $\begin{array}{c}2.07 \pm \\
0.70\end{array}$ & $\begin{array}{c}2.01 \pm \\
0.67\end{array}$ & $\begin{array}{c}2.31 \pm \\
0.66\end{array}$ & $\begin{array}{c}1.63 \pm \\
0.75\end{array}$ & $\begin{array}{c}1.92 \pm \\
0.73\end{array}$ & $\begin{array}{c}2.22 \pm \\
0.69\end{array}$ & $\begin{array}{c}2.10 \pm \\
0.54\end{array}$ & $\begin{array}{c}3.61 \pm \\
3.98\end{array}$ \\
\hline \multirow{4}{*}{$\begin{array}{l}\text { Main place of having } \\
\text { contacts with people } \\
\text { with disabilities }\end{array}$} & family & 3332 & $\begin{array}{c}2.33 \pm \\
0.58\end{array}$ & $\begin{array}{c}1.40 \pm \\
0.40\end{array}$ & $\begin{array}{c}2.50 \pm \\
1.32\end{array}$ & $\begin{array}{c}1.50 \pm \\
0.25\end{array}$ & $\begin{array}{c}2.33 \pm \\
0.90\end{array}$ & $\begin{array}{c}1.78 \pm \\
0.51\end{array}$ & $\begin{array}{c}1.67 \pm \\
0.52\end{array}$ & $\begin{array}{c}2.00 \pm \\
0.58\end{array}$ & $\begin{array}{c}1.96 \pm \\
0.45\end{array}$ & $\begin{array}{c}4.08 \pm \\
0.88\end{array}$ \\
\hline & Relative & 4443 & $\begin{array}{c}2.83 \pm \\
0.88\end{array}$ & $\begin{array}{c}1.85 \pm \\
0.81\end{array}$ & $\begin{array}{c}2.13 \pm \\
0.93\end{array}$ & $\begin{array}{c}2.38 \pm \\
0.43\end{array}$ & $\begin{array}{c}2.25 \pm \\
0.44\end{array}$ & $\begin{array}{c}1.33 \pm \\
0.67\end{array}$ & $\begin{array}{c}1.63 \pm \\
0.78\end{array}$ & $\begin{array}{c}2.00 \pm \\
1.36\end{array}$ & $\begin{array}{c}2.05 \pm \\
0.67\end{array}$ & $\begin{array}{c}4.38 \pm \\
0.55\end{array}$ \\
\hline & School & 3332 & $\begin{array}{c}2.48 \pm \\
0.80\end{array}$ & $\begin{array}{c}2.07 \pm \\
0.59\end{array}$ & $\begin{array}{c}2.11 \pm \\
0.68\end{array}$ & $\begin{array}{c}2.10 \pm \\
0.66\end{array}$ & $\begin{array}{c}2.30 \pm \\
0.64\end{array}$ & $\begin{array}{c}1.74 \pm \\
0.79\end{array}$ & $\begin{array}{c}1.99 \pm \\
0.71\end{array}$ & $\begin{array}{c}2.25 \pm \\
0.69\end{array}$ & $\begin{array}{c}2.13 \pm \\
0.50\end{array}$ & $\begin{array}{c}3.73 \pm \\
0.75\end{array}$ \\
\hline & $\begin{array}{l}\text { Volunteer } \\
\text { activities }\end{array}$ & 4443 & $\begin{array}{c}2.46 \pm \\
0.81\end{array}$ & $\begin{array}{c}2.01 \pm \\
0.63\end{array}$ & $\begin{array}{c}1.91 \pm \\
0.67\end{array}$ & $\begin{array}{c}1.96 \pm \\
0.73\end{array}$ & $\begin{array}{c}2.13 \pm \\
0.74\end{array}$ & $\begin{array}{c}1.56 \pm \\
0.76\end{array}$ & $\begin{array}{c}1.89 \pm \\
0.76\end{array}$ & $\begin{array}{c}2.23 \pm \\
0.71\end{array}$ & $\begin{array}{c}2.01 \pm \\
0.56\end{array}$ & $\begin{array}{c}3.92 \pm \\
0.78\end{array}$ \\
\hline \multirow{2}{*}{$\begin{array}{l}\text { Experience of being } \\
\text { harmed by people with } \\
\text { disabilities }\end{array}$} & Yes & 3332 & $\begin{array}{l}2.67 \pm \\
0.85^{*}\end{array}$ & $\begin{array}{c}2.12 \pm \\
0.56\end{array}$ & $\begin{array}{c}2.13 \pm \\
0.67\end{array}$ & $\begin{array}{c}2.00 \pm \\
0.69\end{array}$ & $\begin{array}{c}2.32 \pm \\
0.65\end{array}$ & $\begin{array}{c}1.77 \pm \\
0.84\end{array}$ & $\begin{array}{l}2.15 \pm \\
0.70^{*}\end{array}$ & $\begin{array}{c}2.38 \pm \\
0.71^{*}\end{array}$ & $\begin{array}{l}2.18 \pm \\
0.50^{*}\end{array}$ & $\begin{array}{c}3.59 \pm \\
0.82\end{array}$ \\
\hline & No & 4443 & $\begin{array}{c}2.40 \pm \\
0.72 \\
\end{array}$ & $\begin{array}{c}1.99 \pm \\
0.61 \\
\end{array}$ & $\begin{array}{c}2.00 \pm \\
0.69 \\
\end{array}$ & $\begin{array}{c}2.01 \pm \\
0.68 \\
\end{array}$ & $\begin{array}{c}2.21 \pm \\
0.68 \\
\end{array}$ & $\begin{array}{c}1.58 \pm \\
0.71 \\
\end{array}$ & $\begin{array}{c}1.84 \pm \\
0.69 \\
\end{array}$ & $\begin{array}{c}2.18 \pm \\
0.68 \\
\end{array}$ & $\begin{array}{c}2.03 \pm \\
0.53 \\
\end{array}$ & $\begin{array}{c}3.90 \pm \\
0.71 *\end{array}$ \\
\hline
\end{tabular}

Values are show as the mean \pm SD.

Significant difference between the two groups $* \mathrm{p}<0.05$.

Table 3. Correlation among the Prejudices against people with disabilities

\begin{tabular}{lllllllll}
\hline Variable & $\mathrm{A}$ & $\mathrm{S}$ & $\mathrm{M}$ & $\mathrm{J}$ & $\mathrm{P}$ & $\mathrm{S}$ & $\mathrm{N}$ & $\mathrm{S}$ \\
\hline Appearance & 1 & & & & & & & \\
Symptoms of disability and treatment & $0.38^{* * *}$ & 1 & & & & & & \\
Marital life and nurture of children & $0.43^{* * *}$ & $0.61^{* * *}$ & 1 & & & & & \\
Job and relationship with colleagues & $0.35^{* * *}$ & $0.66^{* * *}$ & $0.57^{* * *}$ & 1 & & & & \\
Performance of daily tasks & $0.38^{* * *}$ & $0.58^{* * *}$ & $0.59^{* * *}$ & $0.66^{* * *}$ & 1 & & & \\
Social rights & $0.32^{* * *}$ & $0.48^{* * *}$ & $0.50^{* * *}$ & $0.59^{* * *}$ & $0.65^{* * *}$ & 1 & & \\
NIMBY syndrome & $0.40^{* * *}$ & $0.61^{* * *}$ & $0.57^{* * *}$ & $0.67^{* * *}$ & $0.57^{* * *}$ & $0.71^{* * *}$ & 1 & \\
Social service and government support & $0.31^{* * *}$ & $0.44^{* * *}$ & $0.36^{* * *}$ & $0.49^{* * *}$ & $0.53^{* * *}$ & $0.52^{* * *}$ & $0.66^{* * *}$ & 1 \\
\hline
\end{tabular}

Significant difference between the two groups $* * * \mathrm{p}<0.001$. 
Table 4. The regression results showing greatest effect on their attitudes

\begin{tabular}{|c|c|c|c|c|}
\hline Variable & $\mathrm{B}$ & $\beta$ & $\mathrm{t}$ & VIF \\
\hline constant & 0.37 & & 1.47 & \\
\hline Performance of daily tasks & 0.28 & 0.25 & $4.01 * * *$ & 1.29 \\
\hline NIMBY syndrome & 0.59 & 0.57 & $8.92 * * *$ & 1.29 \\
\hline
\end{tabular}

attitudes towards people with disabilities were explained appropriately by the prejudices about performance of daily tasks and NIMBY syndrome $(\mathrm{F}=100.61, \mathrm{p}<0.000)$. As the explanatory power of the two prejudice factors was $54 \%(\mathrm{R} 2=0.54)$, the regression model can be considered an appropriate model for explaining the attitudes of physical therapy students towards people with disabilities.

\section{DISCUSSION}

As a result of examining the prejudices and attitudes of physical therapy students towards people with disabilities, grade and gender did not account for a difference in prejudices against them. In addition, experience of studying with a student with a disability in school before entering University did not lead to a difference in prejudices against people with disabilities. However, students currently having contacts with people with disabilities had weaker prejudices against them ${ }^{4}$. In addition, there was a difference in prejudices against people with disabilities depending on whether they had experienced harm from them ${ }^{5}$. This means that prejudices against people with disabilities can be reduced depending on whether they are currently having frequent contacts with them in daily life ${ }^{4}$, and whether they are currently having positive interactions with them ${ }^{5)}$. Moreover, regarding the difference in prejudices depending on the place where students mainly had contacts with people with disabilities, students meeting them through school or volunteer activities had weak prejudices, similar to those having people with disabilities as family members or relatives ${ }^{6}$. From this point of view, in order to lower prejudices against people with disabilities, it is important that students meet them in school and participate in volunteer work.

Therefore, it is crucial to create an environment where university students currently majoring in physical therapy can have positive interactions with people with disabilities, so that they reduce prejudices, develop positive attitudes, and work with professionalism when they meet them in the field.

Prejudices of physical therapy students towards people with disabilities were all significantly correlated. In particular, the regression analysis showed that prejudices about performance of daily tasks and about NIMBY syndrome affected positive attitudes towards people with disabilities. This result indicates that prejudices about performance of daily tasks and about NIMBY syndrome need to be weakened in order to reduce overall prejudices against people with disabilities and improve positive attitudes towards people with disabilities ${ }^{4)}$.

\section{ACKNOWLEDGEMENT}

The research was has been conducted by the research grant of Sehan University in 2017.

\section{REFERENCES}

1) Jung JS: A study on college students' social distance from people with psychiatric disabilities. Hannam University. Master degree dissertation, 2011.

2) Yang OK: A study on the social prejudice toward people with mental disorder. J Korean Soc Welf, 1998, 35: $231-261$.

3) Yang JE: A study on evaluating the impact of mental disorder awareness improvement program for adolescent. Iwha Woman University. Master degree dissertation, 2017.

4) Han, YS, Back, JK, Lee, JH, Lee, JK: The relationship between the experience with handicapped person and the prejudice on handicapped person. 2002, 1: 294-299.

5) Kim JE, Hwang SY: Perceived social distance of university students with disabilities toward people with disabilities. J Incl Educ, $2010,2: 1-18$.

6) Donaldson J: Changing attitudes toward handicapped persons: a review and analysis of research. Except Child, 1980, 46: 504-514. [Medline] [CrossRef] 